\title{
The Procedure of Constitutional Amendment - Comparative Reviews of European Practices
}

\author{
Luz Balaj $^{1}$ \\ ${ }^{1}$ Teaching Assistant at University of Prishitna, Faculty of Law, Phd Candidate in Constitutional Law, Kosovo \\ Correspondence: Luz Balaj, Teaching Assistant at University of Prishitna, Faculty of Law, Phd Candidate in \\ Constitutional Law, Kosovo.
}

Received: June 4, 2018

Accepted: June 30, $2018 \quad$ Available online: July 2, 2018

doi:10.11114/ijsss.v6i7.3402

URL: https://doi.org/10.11114/ijsss.v6i7.3402

\begin{abstract}
Constitutional changes in a state with written constitution are carried out on the basis of a rule that has been set out by the constitution itself. In practice, many authors refers to articles that define the way of changing the constitution as "rules that define rules" (See for more Tracy Di Fillippo, How to Make Objections to Discovery under the Amended Rules, 25 Pretrial Prac. \& Discovery 1, 2016.) Depending on the content of these rules, two sets of constitutions are generally formulated in the theory of constitutional right. The first are the flexible constitutions, which are amended in a simpler procedure, with a simple majority and in a shorter period of time. While in the second category there are the so-called rigid constitutions. Rigid are called the constitutions that have established a more extended or complicated procedure of amendment, with a qualified majority (more than just a simple majority) and a longer period of time.However, the procedure and the number of members of parliament differ. The main goal of this paper is to analyze those differencies, in oredr to find that how the procedure can affect on the constitutionality of the constittuion amendments. Is the rigid procedure a key for constitutional amendments or not? This is another question that is going to be analyzed by comparing different procedures of constitutional amendments in different countries.
\end{abstract}

Keywords: constittuional amendment, procedure, referendum

\section{The Initiative for Amending the Constitution}

In some countries such as France, Portugal, Belgium, Cyprus, the Netherlands, Norway etc., the proposal for constitutional amendments can be made even by a single member of parliament. (See: EUROPEAN COMMISSIONStudy no. 469 / 2008) But the path of this proposal varies depending on the model or system of governance. If we take a look at the French constitution, Article 81 further specifies that these proposals must come from the President who can initially receive recommendations from the Prime Minister or members of parliament. (See Constitution of France, Article 89 ) While in other countries, this proposal may be subject to an instant debate in parliament. Thus, this shows best what we said earlier that state regulation or the form of government reflects even on the initiative for constitutional changes. Other states have designated a certain number of deputies who have the right to propose constitutional amendments. In theory, this number of deputies is known as a qualified minority. The Constitution of Greece specifies that to initiate an amendment to the constitution, the consent of no less than 50 members of parliament is required. (See Constitution of Greece, Article 110). If we look at the total number of members of the Greek Parliament, this can qualify as one-sixth of the Parliament. Another definition is found if we look at Albania's Constitution. Article 177, which sets out the revision of the Constitution, specifies that: "The initiative for the revision of the Constitution may be undertaken by not less than one-fifth of the members of the Assembly". (See Constitution of the Republic of Albania, Article 177 ). These examples illustrate the practices of countries that require what is called qualified minority. However, in practice, there may also be found constitutions that require the majority of deputies even for the initiative to propose amendments. Such practices for proposing amendments can be found in countries like Georgia, Armenia, Azerbaijan (See VENICE COMMISSION- Study no. 469 / 2008) However, there are also constitutions that have conditioned the proposal of amendments by the parliament with a qualified majoriy of two-thirds. Japan's Constitution in Article 96, which specifies the amendment to the Constitution, states, among other things, that the proposal for constitutional amendments can be made by two-thirds of each chamber, to continue then with the referendum procedure. (See Constitution of Japan, Chapter IX, Article 96.) 
These are some of the practices regarding the initiative for proposing constitutional amendments by the Parliament. Another major issue with regard to the number of deputies who have the right to propose amendments is the nature of the amendment. There are some practices under which the content of the amendment also determines the number of deputies who have the right to propose amendments. This is mainly related to the separation of the constitution in the chapters, where for some chapters the amendment of the articles within them requires a more specific procedure, starting with the proposal of the amendments. We encounter such practice in Ukraine. In Article 154 of the Ukrainian Constitution, referring to the general constitutional changes, it is noted that: "A draft law on introducing amendments to the Constitution of Ukraine may be submitted to the Verkhovna Rada ( Verkhovna Rada is the name of the Ukrainian Parliament, which is unicameral and consists of 450 representatives.) of Ukraine, by the President of Ukraine, or by no fewer National Party Deputies of Ukraine than one-third of the constitutional composition of the Verkhovna Rada of Ukraine". (See Constitution of Ukraine, Article 154.) While the following Article 155 specifies that: "A draft law on introducing amendments to the Constitution of Ukraine, with the exception of Chapter I -"General Principles", Chapter III - "Elections, Referendum" and Chapter XIII -"Introducing Amendments to the Constitution of Ukraine", adopted by the majority of the constitutional composition of the Verkhovna Rada of Ukraine, is deemed to be adopted, if at the next regular session of the Verkhovna Rada of Ukraine, no less than one-thirds of the constitutional composition of the Verkhovna Rada of Ukraine have voted in favor of it". This practice serves to best clarify the relation of the substantial aspect with the procedural one throughout the process of amending the constitution.

The other institution, which in the practice of many states has the power to propose amendments to the constitution, is the Head of State (President). The Constitution of Bulgaria is one of the constitutions that has given this privilege to the President. However, in many constitutions, this right has not been granted only to the Head of State or the Parliament. The Bulgarian Constitutio, has also given the right to propose amendments to the parliament, specifically to one-fourth of the deputies and the President. (See Constitution of Bulgaria, Article 154). Other states that have entrusted the President with the right to propose constitutional amendments are: Croatia, France, Georgia, Russia, Serbia, Ukraine etc.

Unlike the Bulgarian constitutional practice where we saw only the President and Parliament being authorized to propose constitutional amendments, in many constitutions we will notice that such a right has been also given to the Government as an executive body. If we take a look at the Slovenian practice, we will find an authorization to propose constitutional amendments that can be exercised by Parliament through 20 deputies, the Government and thirty thousand $(30,000)$ citizens. (See Constitution of Slovenia, Article 168.) The right to propose amendments directly from a certain number of citizens was also preceded by the Moldovan Constitution. It has set out the number of two hundred thousand $(200,000)$ citizens with the right to vote. ( See Constitution of Moldavia (1994), Article 141, paragraph. 1, point a).

From these practices we can see that the Parliament is the institution that in all constitutions has the right to propose constitutional amendments, unlike the Government, the President or even a certain number of citizens, who are not given the power to propose amendments in every constitution. A particular institution that also has the right to propose the procedure for amendments is that the municipality (as a representative of the local authority). Such a practice is found in the Liechtenstein Constitution where at least four local units may request the initiation of the procedure for amending the constitution. (See Constitution of Lichtenstein, Article 64, paragraph. 4.)

\section{Proceeding the Proposed Amendments}

Relating to the abovementioned practices, where we saw that the Parliament represents the epicenter of the proposals for constitutional amendments, as far as the further proceeding is concerned, the parliament remains the institution with the widest authorizations. The role of parliament after proposing amendments is different from the constitutional practices of different states. In some states where the parliament is the final organ for the adoption of constitutional changes, the procedure continues with the readings, depending on how much readings have been determined by the constitution or by the rules of the parliament. States such as Italy, Turkey, the Netherlands, Denmark etc. have set out two readings. While in some states the constitutional amendments are subject to three readings, such as: Bulgaria, Croatia, Finland, Greece etc. ( See VENICE COMMISSION- Study no. 469 / 2008). The time span in the process of reading the amendments is also of particular importance. In some constitutional practices we find deadlines that must pass from the proposal to the first reading. These terms vary depending on one country to another. Poland and Georgia have set a term of one month from the day the amendments are proposed. Other states have set a deadline of three to six months from the day of the proposal. When we talk about deadlines, the Bulgarian Constitution is worth mentioning, as it has determined that the proposed amendments can not be proposed to proceed in the first reading earlier than one month and no later than three months. (See Constitution of Bulgaria, Article 154, paragraph. 2.) In procedural terms deadlines are also used to determine the periods between the readings, in the countries that have foreseen two or three readings of the amendments.

The role of the parliament in the procedural aspect does not only imply in cases when the parliament is the final authority for the adoption of the amendments. In practice,we will see how some countries have defined the referendum as the final 
solution, but even in these states the parliament has its role in discussing and preparing the draft amendments that may be subject to referendum. Turkey represents one of the most complicated cases in the procedural aspect regarding the amendment procedure. First regarding the role of the President who has the right to return the proposed amendments to the Parliament and the second regarding to the proceeding of amendments to the referendum after a secret ballot in Parliament. Moreover, Turkey has undergone a constitutional change that, apart from the substantive aspect, has received serious criticism from the Venice Commission regarding the non-constitutional process of proceeding. (See: VENICE COMMISSION- Opinion No. 875/2017.)

Among the problems identified by the report of the Commission of Venice are: The first debates took place in the absence of a significant number of deputies from the opposition. Indeed, following a constitutional amendment of 20 May 2016, published in the Official Journal on 8 June 2016 and entered into force on the same day, the parliamentary immunity of several MPs was lifted. On 4 November 2016, the President of the second-largest opposition party HDP (Selahattin Demirtas) and 8 other HDP MPs were taken into detention on remand. There are currently 13 members of HDP who are still in detention, despite the Venice Commission's recommendation to restore parliamentary immunity in Turkey. (See: VENICE COMMISSION- Opinion No. 875/2017.)

Second, under Article 175 of the Constitution and Article 94 of the National Assembly's Rules of Procedure, the voting had to take place by secret ballot. Indeed, Article 175 of the Constitution stipulates that "the adoption of a proposal for an /constitutional/ amendment shall require a three-fifths majority of the total number of members of the Assembly by a secret ballot". The Rules of Procedure of the Grand National Assembly of Turkey specify that for the purpose of a secret vote, "three circular ballot papers, one ëhite, one green and one red, are simultaneously given to each deputy. The circular ballot paper to be used in voting shall be placed into the related box. The other two are left at the indicated space" (Article 148). Moreover, according to the Commission of Venice, this rule was not fully respected during the parliamentary vote on the constitutional amendments in question. During the vote, several deputies voting for the amendments cast their votes openly, showing the white ballot paper before placing it into the box. The whole procedure was tele-recorded and shown on public media. It was made possible to see the stamp in some deputies' hand. Moreover, unused ballot papers were recollected after the vote and allegedly used to identify those who, especially among the AKP and MHP members, did not vote for the amendments. (See: VENICE COMMISSION- Opinion No. 875/2017.)

The case of Turkey is one of the most recent examples from which a conclusion can emerge about the fact of interconnection in the procedural and substantive aspect of the constitutional amendment. Since it is apparent that these amendments that have been criticized in a substantial aspect in terms of violating democratic values, the rule of law and the deformation of the principle of the unity of the people, emerge also from a procedure where procedural irregularities have been evidenced.

In the procedural aspect, many constitutions have also defined a limitation that has to do with the time when the constitution can not undergo a process of change. Here we refer to the state of emergency. While theydefine procedural details regarding the proposal of amendments, many constitutions have taken care to explicitly clarify that none of the institutions having the power to propose amendments can do so at a time when the country has declared a state of emergency. If we take a look at the Constitution of Albania, Article 177, immediately after defining the institutions that have the right to propose amendments clarifies that: "No revision of the Constitution can be undertaken during the time when extraordinary measures are imposed. Also the Polish Constitution states clearly that: "During the period of introduction of extraordinary measures, the following shall not be subject to change: the Constitution, the acts on elections to the Sejm, the Senate and organs of local government. (See Constitution of Poland, Article 228,paragraph 6). .Similarly, Article 147(2) of the Constitution of Lithuania provides that: "During a state of emergency or martial law, amendments to the Constitution may not be made", and Article 157 of the Constitution of Ukraine provides that "The Constitution of Ukraine shall not be amended under the conditions of martial law or a state of emergency".

A similar content of forbidding constitutional changes to the state of emergency has been also defined in the constitution by Belgium, Georgia, Spain, Serbia etc. (See VENICE COMMISSION- Study no. 469 / 2008.)

In this aspect, the Venice Commission has again found procedural irregularities in the recent process of amending the Turkish Constitution. The report states that: "The procedure of parliamentary discussion and adoption of the constitutional amendments has taken place during the state of emergency. The referendum is planned for 16 April 2017, when the state of emergency will have been in force for almost nine months consecutively. The Venice Commission has repeatedly stressed that "transparency, openness and inclusiveness, adequate timeframe and conditions allowing pluralism of views and proper debate of controversial issues, are key requirements of a democratic Constitution-making process". ( See VENICE COMMISSION- Opinion No. 875/2017). Moreover, the Commission of Venice emphasizes that: "The adoption of a new and good Constitution should be based on the widest consensus possible within society and [...] "a wide and substantive debate involving the various political forces, non-government organisations and citizens 
associations, the academia and the media is an important prerequisite for adopting a sustainable text, acceptable for the whole of the society and in line with democratic standards. Too rigid time constraints should be avoided and the calendar of the adoption of the new Constitution should follow the progress made in its debate." Open and free public discussions should take place "in an atmosphere favouring such discussions". "Moreover, if and when a popular referendum is held, it is of great importance that this is done properly, in a way which ensures clarity and transparence, and which presents the electorate with clear and precise alternatives. (See VENICE COMMISSION- Opinion No. 875/2017).

However, in the interests of fairness it is good to note that the Turkish Constitution does not contain a concrete norm that prohibits the process of constitutional changes during the state of emergency. Also it is important to mantione some other fact whan it comes to Turkeye. As Saffet Akkaya has mantioned: Turkey is one of the main role players in the Middle East since the medieval ages. It has broadly effected the political, economic, and military interactions amongst Middle Eastern societies, as well as the politics of great powers in the region. ( See Saffet Akkaaya 2012). Any kind of constitutional destaibilty in Turkey, can easy afect the political stability in Middle East!

Another procedural element related with time or time limits is the constitutional preordainment over the periods of constitutional change. How does this work? States like Portugal and Greece have set out in their Constitution that the constitutional amendment procedure can only begin after a period of five years from the last amendment. ( See Constitution of Greece, Article 110, paragraph. 6). While the Greek Constitution has determined this period by not providing any alternative, the Portuguese Constitution has an exception to this rule. Whereas the first paragraph of Article 284 states that: "The Assembly of the Republic may revise the Constitution five years after the date of publication of the last ordinary revision law", the second parahgraph clarifies: "However, by a four-fifths majority of all the Members in full exercise of their office, the Assembly of the Republic may take extraordinary revision powers at any time." ( See Constitution of Portugal, Article 284, paragraph. 1 and 2). This four-fifths majority is undoubtedly a new practice in terms of parliamentary rules, as it is too difficult to achieve in practice.

The other and final aspect of the procedure of parliamentary amendments has to do with the elections. The constitutionality of the constitutional amendment, in the procedural aspect, in some states is realized only when elections are held in the process of the amendment. In practice there are two forms of electoral engagement during the process of amendment. In the first practice, the elections are held before the vote, so the preliminary legislature makes the proposal of the amendments and they only come into force if voted by the subsequent legislation. While in the second practice, after the constitutional amendments are voted, the parliament is dissolved and elections for the new legislature are held, based on the amended constitution. This practice has shown that constitutional amendments are often usedas electoral objects or instruments, especially in the practice of elections after the draft amendments. The Constitution of the Kingdom of the Netherlands is one of the constitutions that defines the constitutionality of the constitutional amendment with elections as a legitimizing element. In Article 137, it clarifies that: "The Lower House shall be dissolved after the Bill referred to in the first paragraph has been published. After the new Lower House has assembled, the two Houses of the States General shall consider, at second reading, the Bill referred to in the first paragraph. The Bill shall be passed only if at least two thirds of the votes cast are in favour". (See Constitution of the Netherlands, Article 137, paragraph. 3 and 4). Such a practice of holding elections after constitutional amendments has been also set by the constitution of Belgium, Estonia, Norway, Spain etc. (See VENICE COMMISSION- Study no. 469 / 2008).

\section{Referendum as an instrument or mechanism in the process of constitutional changes}

The referendum is one of the forms of direct participation of citizens in decision-making. As such, it has been implemented in many practices of different states even with regard to the constitutional change process. In the past, the referendum was used in two forms. Firstly, when the amendment procedure has previously determined the proceeding of amendments to the popular referendum. Secondly, this has been done to reach a popular consensus, in the absence of consensus among the people's representatives. (See Robert Luce-1930).

Although at first glance it seems like an instrument that only requires popular approval, in the procedural aspect, the organization of the referendum requires the fulfillment of certain criteria and procedures defined precisely by the constitution. It is precisely for this reason that the referendum finds space to be addressed in this study, since even constitutional changes that have been made through a referendum may bring a non-constitutional amendment, at least from a procedural point of view.

The referendum continues to be present today in the practice of constitutional amendments in many states. Depending on the constitution, the referendum is found in some constitutions as optional, while some others have defined it as mandatory.

Some of the forms or ways in which a referendum is defined during the process of constitutional changes are:

- on a mandatory basis for any amendment passed by Parliament; 
- on a mandatory basis as a reinforced procedure for amending particular provisions enjoying special protection;

- on a mandatory basis for "total revision" or adoption of a new constitution;

- $\quad$ on an optional basis, upon demand by Parliament, by popular initiative, by local authorities or upon decision of the Head of State. (See VENICE COMMISSION- Study no. 469 / 2008).

In practice, various constitutional definitions can be found regarding the nature of the referendum, ie whether it is mandatory or is dependent upon a request from a particular institution. For example, in the Azerbaijani Constitution, it is decisively clarified that "the changes in the Azerbaijani Constitution can only be adopted through a referendum". ( See Constitution of Azerbaijan (1995), Article 152).

Even in the mandatory referendum, set out by the constitution itself, but also for the referendum for which the Parliament or the President decides, in practice there are time limits for its implementation.

In terms of an efficient procedure, Spain seems to have set the fastest time-frame for organizing the referendum. Paragraph 3 of Article 167, which refers to the amendment, specifies the deadline of only 15 days for the organization of a referendum on the issue of constitutional amendment, after the amendments have been ratified in both chambers of the Spanish Legislature. (See Constitution of Spain (1978), Article 167, paragraph. 3)

In the analyzed practices, the case of Spain seems to be in practice the fastest case in the procedural sense, since as we will see, other states have set a deadline for the referendum for a longer period after the adoption of the amendments in the parliament

In some states, the constitution has set a deadline to organize a referendum after the parliament's decision to amend the constitution. Such an example is found in Estonia. Article 164 of the Estonian Constitution, besides requiring a qualified majority of three out of five (3/5), clarifies that no constitutional amendment can enter into force without being subject to a referendum, which should be held three months after the ratification of the amendment by the (Rigikog) legislative. (See Constitution of Estonia (1992), Article 164).

Other states like the South Korea and Romania have set a 30-day deadline for the referendum after the amendments have been ratified by the legislature. Other countries such as Albania, Poland and Serbia have set a deadline of two months (60 days) for the process of constitutional amendments to the popular referendum. ( See For more Constitution of South Korea, Romania, Albania, Poland and Serbia)

As far as deadlines are concerned, some states have set longer deadlines with their constitutions. Among the countries that have set a considerable deadline for referendum proceedings are Denmark and Malta. These states have set the six-month deadline, within which amendments that have been ratified by the legislature, must be subject to referendum. These are some of the practices of different states regarding the definition of the constitution over the deadlines for the referendum to be conducted in order for the process to result in completely constitutional amendments in terms of the procedural aspect. The reason why great importance is given to deadlines within which the referendum must be held, is closely linked to the constitutionality of the constitutional amendment that is the main issue of this study. In 2000 , the Moldovan Constitutional Court had rejected a constitutional amendment procedure by impeding the non-constitutional organization of the referendum as the prescribed deadlines had invalidated the citizens to exercise their right to vote in the referendum. ( See the Decision of the Constitutional Court of Moldavia 7/12/2000, MDA-2000-3-10).

But in referendum there is also another important element, especially for the practices of states where the referendum is not mandatory. So, as noted at the beginning of the referendum discussion, there are different states whose constitutions determine the referendum as an alternative tool or mechanism throughout the process of amending the constitution. It is important to clarify that if such a procedure is alternative, then how it is decided to include or not include the referendum in the amendment procedure. If we go back to Spanish practice, we will see a very interesting definition regarding the decision to proceed with the constitutional amendment in a nationwide referendum. The Constitution there specified that it is enough for the request to come only from a tenth (1/10th) of the representatives from both chambers in order for the ratified amendments to be submitted to referendum. (Constitution of Spain (1978), Article 167, paragraph. 3).

Unlike Spanish practice where this minority is required (1/10), a completely different practice has been determined by the Estonian Constitution, which also sets the referendum as an alternative mechanism. In Estonia, in order for one or more amendments to be submitted to a referendum, the Constitution has determined that such a request should be voted on by three-fifths (3/5) of the Estonian Riigikog (Parliament).

The last issue to be discussed with regard to the referendum and its validity is the definition of the constitution for the nature of the majority to vote on in a referendum in order for the referendum to be constitutional. In practice, most 
constitutions have determined that more than half of all voters constitute the required majority in order for the constitutional amendment to get passed in the referendum. But this is not the only practice. There are some specifics that indicate the fact when constitutional amendments are considered to have passed in a referendum. For example, in Armenia, the draft amendment shall be deemed to have been approved if more than one-half of the participants to the vote but not less than one-fourth of the registered citizens have voted in favor of it. (See VENICE COMMISSIONStudy no. 469 / 2008). Also, Montenegro has determined another majority in terms of the needed majority to pass an amendment through a referendum. Some Articles of the Constitution of Montenegro, in order to pass in the referendum, are required to be voted by three-fifths (3/5) of all voters participating in the referendum. (See Constitution of Montenegro (2007), Article 157).

Regarding the determination of the needed majority to pass constitutional amendments in referendum, a special case is presented by Albania. In Albania, the regulation of this majority is determined not by the Constitution, but by a special law on referendum. ( See VENICE COMMISSION- Study no. 469 / 2008).

Based on these comparisons, it can be said that the procedural aspect, or better said the constitutional definition of the procedure, differs from one state to another. Thus, the constitutions have specified procedures that in some way also show the weight of the constitutional act whose articles are subject to a change. As seen in practice, the courts exercising constitutional control over the amendments, whether Constitutional or Supreme, attach great importance to the procedural aspect throughout the process of constitutional change at all stages of the proceedings.

\section{The Apriori Review of the Constitutionality of Constitutional Amendments}

One of the elements that makes up the distinction between the centralized and decentralized constitutional review model is precisely the preliminary (apriori) review of constitutional amendments. In some countries, mainly in Europe, constitutional courts have been given a special role in the process of amending the constitution. This role consists in involving the constitutional courts in assessing constitutional amendments before they are proceeded for final ratification in parliament or referendum, if the latter is set out in the constitution. (See Constituion of Ukraine, Kyrgyzstan, Moldavia and Kosovo)

The inclusion of constitutional courts in the constitutional review of constitutional amendments before their final ratification, differs from state to state in two key segments. The first with regard to the substantive aspect, therefore, what is the role of the court to evaluate the constitutional amendments. We will see in practice that some courts may assess constitutional amendments regarding their constitutionality, in conformity with the constitution as a whole, while some other courts have a certain segement to whom they assess the constitutionality of the amendment, such as human rights and freedoms.

The other distinction with regard to the involvement of the constitutional courts is interconnected with the procedural aspect, if the courts have an ex officio authorization to be included in the constitutional review of the amendments in the process of adoption, or the constitutional court's inclusion is made only on a request of a certain institution.

Regarding the substantive aspect, the Constitutional Court's competence to evaluate the constitutional amendment, as mentioned above, there are two practices. The first has to do with the constraint of the Constitutional Court regarding its role in the review of amendments. The Constitution of Ukraine is one of the Constitutions that has specified the scope of the Constitutional Court regarding the assessment of amendments. Specifically, the Ukrainian Constitution has given the Constitutional Court authority to assess whether the constitutional amendment contradicts two other Articles of the Constitution, Article 157 and Article 158. Article 157 specifies that the Ukrainian Constitution cannot be amended if the proposed amendment intends to undermine the freedoms and rights of the Ukrainian individual and citizen, or if the constitutional amendment violates the independence, sovereignty or territorial integrity of Ukraine. Thus, the Constitutional Court, as we can see in this Article, has the power to review the constitutionality of the amendment in three areas of substantial nature: human rights and freedoms, independence and sovereignty of the state and territorial integrity. The other issue where the Constitution has given access to the Constitutional Court is related to the next Article, 158. This Article gives the Constitutional Court the power of evaluating a procedural aspect as it establishes that a constitutional amendment that has not been ratified by the Parliament, cannot be brought back to the vote earlier than one year from the day it was rejected. Thus, the first Article establishes substantial responsibility, while the latter defines more the procedural responsibility.

The second practice where the court has been given a limited authority to assess the constitutionality of the amendment is found in the Constitution of Kosovo. The Kosovo Constitution authorizes the Constitutional Court to evaluate whether a constitutional amendment aims to reduce the human rights and freedoms set forth in Chapter II of the Constitution. ( Constitution of Kosovo (2008), Article 113, paragraph. 9).

The second aspect that differs from the practice of one country to another regarding the role of the Constitutional Court 
in evaluating the amendments was the way of incorporating the constitutional court into the constitutional review process. Here, the constitutions of various states have a variety of practices. Some therefore see the role or involvement of the Constitutional Court as necessary during the constitutional amendment process, considering this inclusion as a guarantee of deviations from non-constitutional amendments. (See for more Constitution of Kosovo, Moldavia and Ukraine)

One of the most illustrative examples is the case with the procedure set out in the Moldovan Constitution. The Constitution there stipulates that: "Any draft for constitutional amendments should be processed in Parliament together with the advisory opinion approved by at least 4 Constitutional Court judges." The Constitutional Court of the Moldovan Republic is composed of a total of 6 judges.

Unlike Moldova, Kosovo, Ukraine, etc., which incorporate the constitutional court's inclusion into the constitutional review process as necessary by the Constitution, other states have left the inclusion of the Constitutional Court to the will of a certain number of deputies, or the President. In the Turkish practice, the Constitutional Court may review constitutional amendments (the procedural aspect only) if requested by the President of the Republic or one fifth (1/5) of the deputies. (See VENICE COMMISSION- Study no. 469 / 2008.) Unlike Turkey, where the incorporation of the Constitutional Court is done by the President or one-fifth of the deputies, in Azerbaijan for example, the incorporation of the Constitutional Court is sets out by the initiative for amendment. So, if the amendments were initiated by the Parliament and the President, they should be subjected to a review by the Constitutional Court. (See Constitution of Azerbaijan, Article 57). If constitutional amendments are decided to be proposed for a referendum, then the Constitution has specified that the Constitutional Court cannot be included in the process of reviewing the amendments. Another determining element for incorporating the constitutional court into the assessment of constitutional amendments is the nature of the amendment. At the end of this study on the practices of different constitutions for the involvement of the constitutional court in the process of amendment, it is important to also mention the model set out in the Constitution of Kyrgyzstan. Similar to other practices, the Kyrgyz Constitution has determined that the Court is competent to provide conclusions on the draft of the proposed amendments. (See Constitution of Kyrgyzstan, Article 97, paragraph. 6, point 3). But the important thing here is that in Kyrgyzstan there is no constitutional court as in the mentioned practices, but the competent authority to be included in the constitutional review of the amendments, is the Constitutional Department within the Supreme Court of Kyrgyzstan. So, while Supreme Courts exercise constitutional review, concrete - a posteriori, even for constitutional amendments, as seen especially in the doctrine of constitutional issues, the case of Kyrgyzstan presents us a special practice, since the Supreme Court there, seen from the constitutional position, is organized within the regular judiciary. But seeing its role in the process of constitutional amendment, this court takes the features of a constitutional court.

\section{Conclusion}

Looking at the practices outlined above, the inclusion of constitutional courts appears to be a reflection that has derived from the process of drafting the constitution and the circumstances surrounding the drafting process. The specifics that differentiate the constitutional practices from one state to another are as a result of the impact of the past. In countries that have faced a constitutional instability as a result of frequent changes, there is a growing role of the constitutional courts, especially in guaranteeing no violation of individual freedoms and rights by constitutional amendments. While in states in which democracy has been stabilized longer, there are elements of a more flexible procedure. In general, the concentration of constitutional reforms in Parliament, in terms of the procedural aspect, has served and contributed to a more stable democracy. However, as in any other practice, there are exceptions to the amendment procedure as well. In this case, the practice of recent constitutional changes in Turkey, as we have seen, is accompanied with serious remarks regarding the followed procedures. This fact brings another argument to the interconnection of the constitutional amendment procedure in the content of the amendment. Thus, there is no way that a non-constitutional procedure results in a constitutional amendment process. Also the case of Turkey can be an used as an example that can show the importance of procedures on the process of constitutional changes. The role of political parties, especially the role of opposition is important in order to have a democratic process of Constitutional Changes. In Democracy, any idea or tendency to leave the opposition out of the process, can reflect later on the validity of constitutional amendment.

\section{References}

Decision of the Constitutional Court of Moldavia 7/12/2000, MDA-2000-3-10.

EUROPEAN COMMISSION FOR DEMOCRACY THROUGH LAW (VENICE COMMISSION) REPORT ON CONSTITUTIONAL AMENDMENT, Adopted by the Venice Commission at its 81st Plenary Session (Venice, 11-12 December 2009) Strasbourg, 19 January 2010 Study no. 469 / 2008

EUROPEAN COMMISSION FOR DEMOCRACY THROUGH LAW (VENICE COMMISSION) TURKEY OPINION ON THE AMENDMENTS TO THE CONSTITUTION, Adopted by the grand national assembly on 21 January 
2017 and to be submitted to a national referendum on 16 April 2017, Adopted by the Venice Commission at its 110 th Plenary Session (Venice, 10-11 March 2017) Strasbourg, 13 March 2017 Opinion No. 875/2017.

Robert, L. (1930). Legislative Principles: History and Theory of Lawmaking by Representative Government (1930).

Saffet, A. (2012). Rise of political Islam in Turkey and its Effects on Turkish-Syrian Relations, 4 Contemp. Readings L.\& Soc. Just.226 (2012)

Tracy, D. (2016). How to Make Objections to Discovery under the Amended Rules, 25 Pretrial Prac. \& Discovery 1, 2016.

Constitution of the Republic of Albania

Constitution of Greece

Constitution of France

Constitution of Japan,

Constitution of Ukraine,

Constitution of Bulgaria,

Constitution of Slovenia,

Constitution of Serbia

Constitution of Lichtenstein,

Constitution of Poland,

Constitution of Azerbaijan

Constitution of Montenegro

Constitution of Kosovo

Constitution of Turkey,

Constitution of Kyrgyzstan,

Constitution of Moldavia

Constitution of Denmark

Constitution of Malta

Constitution of Romania

Constitution of Azerbaijan

\section{Copyrights}

Copyright for this article is retained by the author(s), with first publication rights granted to the journal.

This is an open-access article distributed under the terms and conditions of the Creative Commons Attribution license which permits unrestricted use, distribution, and reproduction in any medium, provided the original work is properly cited. 